\title{
Model poverty reduction through social and economic institutional empowerment of poor communities in South Sulawesi
}

\author{
Syamsu Nujum, Annas plyriadi, Ramlawati \\ lecturer at the faculty of economics of UMI Makassar \\ e-mail:syamsu.nujum@gmail.com
}

Article history:

Received, August 02, 2017

Revised, September 30, 2017

Accepted, November 292017

Keywords:

Economy

Empowerment

Institutional

Implementation model

Social
This research aims (1) to reviewing the extent to which the role of the Government in implementing the model of empowerment of marginal/poor communities through mentoring program in learning, (2). Reviewing and explain the benefits of implementing the poor's empowerment program to alleviate poverty, (3). To review how to implement the poverty alleviate model that is more in line with the local wisdom of the people of South Sulawesi.

The Research results show that (1). Institutional social and institutional Economics that exist in the community in the region Mamminasata South Sulawesi in generally not have the ability to empower the community because it has not received optimal support from the government and private. (2). In general, the education and skills of the community are still low so that people face limitations in living their lives, especially in economic activities, so tend to be unproductive and powerless and become poor.

Copyright () 2017 Indonesia Prime. All rights reserved.

\section{Introduction}

Poverty is a crucial problem faced by all countries in the world, whether developed countries are developing countries moreover. Poverty is currently still a global issue. Means that poverty does not just become a major problem in third world countries, but also is an issue in other industrialized nations, it at least can be observed in the data that suggests, that in the United States in 1980 still contained 2.8 million people. Who subsidized, more than half of the Group were still classified as poor, as it is has said (Sulaiman; 1996 in Muhtar, 2005).

This research takes the theme of alleviating poverty, since poverty phenomenon is a phenomenon that is very interesting for a very urgent, examined in this research is how to realize a Model of poverty alleviation that is effective so as to speed up the help our brothers who belong in the category of poor people to get out of poverty.
In poverty reduction, it is necessary a change of mindset and paradigm in poverty reduction programs related to the creation of a situation where the poor given greater access to the assets needed to achieve the minimum necessities of life. Also the Government's partiality in giving access to capital, technology, production and market access so that they can improve their lives through the development of local businesses. To achieve such expectation, then local institutional communities (economic and social institutions) should be able to encourage the creation of the fulfillment of the needs of the poor. For example, the availability of health facilities, education and facilities support the sustainability of the economic life of the community to realize a change from being a marginal society that advanced his social and economic.

Based on the phenomenon of extreme poverty looks at in the community, then the perceived need to do studies of implementation against the Model of poverty alleviation through 
empowerment of social and Institutional economics. There is a presumption that the Government-run strategy in combating poverty through a variety of programmes, is seen still have side weaknesses, because government programs during this time (the first lamp up to now) is still on landscape policy which is only momentary, and the handling is not yet a program rooted in the community, because it is less work.

This research tries to build and implement models of poverty alleviation through Institutional social and economic empowerment of the community by performing fundamental factors which trigger the mapping of the incidence of poverty. Implementation of the Model produced in this research is believed to be able to help the community in doing access to economic and social activities, which in turn can raise the appearance of social capital that is also a big potential can encourage the economic and social development of the community. Therefore this research is expected to have the urgency of implementing the model in alleviating poverty in Sulawesi, Indonesia in particular and in General.

\section{THEORETICAL STUDIES}

\section{a. The theory and the concept of Empowerment}

Community empowerment efforts is a central issue that is often leveled by the Government and the community, but at the moment the issue of community empowerment is still in the stage of socialization to search for a model of development. Accordance with the certain groups of people, given the complexity of the problems, faced the community itself either in individual or groups.

Local community development is a process which aimed at creating the social and economic advancement for communities through active participation and initiative as well as the initiative of the members of the community itself. Members of the public are viewed not as a problem but rather the client system as a unique community and have the potential; it's just that the potential has not fully developed. The development of the local community is essential a process of interaction between members of the local community is facilitated by a social worker. Social workers help raise awareness and develop their ability to achieve the expected objectives (Suharto 2005).
More advanced by the team of Crescent (2003), that Social Security can be defined broadly as the public, including the actions undertaken by the community, to protect the poor and weak of an adverse change in the standard life, so that they have an acceptable standard of living (The World Bank Research Observer, 1991). Furthermore, the scope of social security is covering:

- Family empowerment: social security systems in an area of the community is determin by the process of empowering the family as a social unit and the smallest kinship in the family.

- Empowerment Community Area: social security of the enclosing region in empowerment, in the sense of social security of the system was built starting from the resilience of the region smallest community that allows it does planning with decision making for the construction of social security system.

- Social Creative Energy: empowerment is the ability Community jointly utilize a variety of resources available. This energy is the key strength of the possible emergence of a system of independent people (Sumardjo, 1994, Sayogyo, 1994, Uphoff, 1992). The social energy sourced on three interrelated elements, namely: (1) ideas (ideas), (2) dream (ideal), (3) fraternity (friendship).

- Local Institutional empowerment: Social Security Systems developed and implemented by leveraging existing local institutional. The establishment of a new institution is not a priority of the development. The new institution will be built if people themselves who need it and the old institutions are no longer able to run its function in the development of social security.

According to Kieffer (1981) in Suharto (2005), empowerment includes three dimensions that include the competency in psychology, social and political ability, and competence of participatory (Suharto, 1997, Pearson et al., 1994), also proposed the three dimensions of empowerment that refer to the following: A development process which originated from individual growth later develops a larger social 
change. According to Kieffer (1981) in Suharto (2005), empowerment includes three dimensions that include the competency in psychology, social and political ability, and competence of participatory (Suharto, 1997, Pearson et al., 1994), also proposed the three dimensions of empowerment that refer to the:

- A development process which originated from individual growth later develops a larger social change.

- The resulting liberation of a social movement, which started from education and politicization and politically people infirm and then involves the collective efforts of the weak people to gain power and change structures are still pressing (Pearson et al., 1994)

\section{b. Concepts and indicators of Poverty}

In general, the concept of poverty can be distinguished from a different point of view, but can be differentiated in three forms, as has been said by Townsend in 2008), Ridwan as follows:

a. Absolute poverty, i.e., a situation where income level community owned is under the poverty line, or a number of its revenue could not be sufficient to meet the minimum basic needs of life. Therefore it is often called absolute poverty with poverty-natural.

b. Relative poverty is a form of poverty by looking at what percentage of national income received by a group of the population with a particular class of income compared to the proportion of national income earned by the Group the population with other income groups. (based on the dimensions of space and time).

c. Cultural poverty, i.e. form poverty refers to the attitude of a person or a community because of their cultural factor in the unwilling to attempt to improve the level of life although there is up an outside party to help him. Even in the theory of the "culture of poverty" has been declared that poverty can arise as a result of the values or culture embraced by the poor themselves, such as lazy, easily succumbed to fate, lacking the work ethic and so on.

\section{c. The concept and theory of Institutional.}

There is a belief that institutional (institutional) can be a source of efficiency in economic progress that has been accepted by most economists, even the most liberal thought. It's just that until now still not their clarity regarding the meaning and definition of institutional. At least, though in the same substance through rate many economists define institutional with variegated perspectives (Yustika: 2006.37). North (1994) in Yustika (2006:41) interpret as institutional rules that humans deviate behavior limit (human devised) to build the structure of the interaction of the political, economic, and social. In this context institutional has three components, namely the rules of formal (formal institution), informal (informal institution), and suppressor mechanisms (enforcement mechanism).

\section{THE RESULTS OF THE EXTERNAL AND ACHIEVED}

\section{An Overview of The Area of Mamminasata}

Mamminasata area Development is an area of concern to the Government in encouraging the creation of development and economic growth in the region, in hopes of giving the spill effect either for or back of the area of Mamminasata and other regions outside of the area of Mamminasata. It became important in creating new growth Centre within the region and outside the region as the catalyst of the development progress of the region. Of the four regions, the city of Makassar as the urban center that has a strategic position in the area of influence There are nearby. Makassar city has many facilities that support the creation of a huge impact economic growth for the whole region of Eastern Indonesia. Makassar city as the gateway of Eastern Indonesia would certainly be a lot of benefit from the current economic turnaround from time to time. Benefits arising in Makassar city will also encourage the growth of the surrounding area such as Maros Regency, Regency Takalar, and Gowa,

\section{a. Regional Income According To The Regency of The City Area Mamminasata}

The magnitude of the gross domestic product of a region will give impact on the economic growth of the area concerned so that continuous regional economic growth and society will receive high welfare Aligns economic growth areas that are experiencing high growth. However, cannot be guaranteed that high economic growth will be high welfare creating on the concerned because it may be high economic 
growth will bring huge imbalances creating/, so that enjoy the prosperity of economic growth happening is certain groups.

Table 1 Gross Domestic Products according to the Regency/City on the 2013-2015 Year Mamminasata Area (in a million rupiahs)

\begin{tabular}{|l|r|r|r|}
\hline \multirow{2}{*}{ District/City } & \multicolumn{3}{|c|}{ Years } \\
\cline { 2 - 4 } & \multicolumn{1}{|c|}{2013} & \multicolumn{1}{c|}{2014} & \multicolumn{1}{c|}{2015} \\
\hline Makassar & $88.363 .458,08$ & $100.398 .532,82$ & $114.171 .730,97$ \\
\hline Maros & $11.966 .918,04$ & $13.662 .536,71$ & $15.767 .633,66$ \\
\hline Gowa & $10.713 .900,02$ & $12.044 .913,18$ & $13.734 .059,55$ \\
\hline Takalar & $5.004 .184,86$ & $5.882 .260,83$ & $6.809 .955,87$ \\
\hline
\end{tabular}

The Source of the BPS; District/city in 2016

In table 1 it can be seen on the GRP magnitudes each region in the area of Mamminasata, Makassar City shows as the year 2013 amounting to $88,363,458.08$ million, the year 2014 GDP amounting to 100,398,532.82 million, in the year 2015 GDP amounted 114,171,730.97 million. Likewise, on the Maros looks at the Year 2013 amounting to $11,966,918.04$ million, amounting to 13,662,636.71 million the Year 2014 and 2015 Years GDP amounting to 15,767,633.66 million. Likewise, Gowa by constant prices of the year 2010, the year 2013 amounting to IDR 110.713 .900 .02 million, the year 2014 GDP Gowa of 12,044,913.18 million and the year 2015 amounting to $13,734,058.55$ million. Takalar Regency and the last in the year 2013 amounting to $5,004,184.86$ million, the year 2014 GDP of $5,882,260.83$ million and the year 2015 GDP amounted to $6,809,955.87$ million.

\section{Mapping Poverty in Regency/Kota Mamminasata}

Mapping Poverty can know through the percentage of the poor population in each region. Based on the percentage of the number of poor people in each county and City can be a map or clues about the situation of the poor. Such data is crucial in the member's instructions and direction in determining the strategy and policy development of an area, especially in drawing up community empowerment strategies in combating poverty.

The phenomenon of poverty that occurred in the region in the area of Mamminsata, i.e., the city of Makassar, district of Maros, Regency Gowa and Takalar Regency, where a rise in Income Gross Domestic Product which was followed by a rise in the number of poor population presentation. Ideally that if an increase in the income of an area, then it is expected that the poor presentation population will be According to. A phenomenon that occurs in the area of Mamminasata the member's indications that the Ascension of income for communities experiencing inequality among groups of people. This means that the increase in the gross domestic product was only enjoyed by certain groups such as owners of capital, and large and medium businesses so that groups of people who are at the/Usaha Household Micro businesses have not enjoyed a rise of gross national income happens.

Table 2 percentage of the poor population according to the Regency/town in the area Mamminasata of the year 2012-2013

\begin{tabular}{|c|c|c|}
\hline \multirow{2}{*}{ District/City } & \multicolumn{2}{|c|}{ Years } \\
\cline { 2 - 3 } & 2012 & 2013 \\
\hline Makassar & 5,02 & 4,70 \\
\hline Maros & 12,55 & 12,94 \\
\hline Gowa & 8,01 & 8,70 \\
\hline Takalar & 9,95 & 10,42 \\
\hline
\end{tabular}

Source: BPS Regency/town Year 2016

The magnitude of the number of poor population will potentially create social problems of which decrease the quality of human resources, the emergence of social inequality, and jealousy, the 
disruption of social and political stability and increasing numbers criminality. In turn, these conditions inhibit the economic development of the region and make it difficult to get out of failed.

Poverty became phenomenal in handling because poverty has a multi-dimensional so sometimes in the response through the empowerment of finding things that don't fit in with what expected. Poverty should not be seen only from income, and a place to live, but had evolved into abroad with a more complex dimension.

Causes of poverty can be seen from its geographical characteristics, i.e., by determining where the poor are concentrated. This geographical aspect can be divided into the spread of cities and villages, beaches and nonbeach or from the perspective of gender between male and female.

The poverty that occurs in the area of mamminasata can distinguish into two categories:

Absolute poverty, where the income level of the poor below the poverty line, it's no revenues quite meet minimum basic needs for everyday life ...

One of the informants ' Beggar "roadside found in the Makassar City States that we are doing this because it can no longer work because of our disability due to Leprosy disease because it is there that help us to deliver to where begging and also drove back to the place we live. Makassar (June 15, 2017).

b. Relative poverty, one including the poor relative in have been able to meet the

\begin{tabular}{|c|c|}
\hline A major problem faced & Description of the problem encountered \\
\hline The Fulfillment of Basic Needs & $\begin{array}{l}\text { - Still, many people who own a home is not livable, } \\
\text { and most still do not have a home of its own } \\
\text { - There are still many households that don't yet have } \\
\text { a decent MKC } \\
\text { - Many family members who are not able to put an } \\
\text { end to his studies on secondary. } \\
\text { - There are still many households that have not been } \\
\text { able to meet the need to eat regularly; there are still } \\
\text { difficulties to earn income to finance its needs. }\end{array}$ \\
\hline $\begin{array}{l}\text { The availability of the principal } \\
\text { activity is supporting } \\
\text { infrastructure }\end{array}$ & $\begin{array}{l}\text { - Supporting facilities for the production has not been } \\
\text { sufficient in particular farmers } \\
\text { - Marketing results of Community production are } \\
\text { very limited. }\end{array}$ \\
\hline
\end{tabular}

necessities of life, but it is still much lower compared to the State of the surrounding community.

c. Cultural poverty, where the poor because of their cultural influence of resigned received the case they don't want to strive to improve the level of life and receive the state what it is. They caught in a cycle of poverty is naturally without them even realizing.

The various policies in the structure of local government Districts have been carried out and the city in South Sulawesi in the form of direct cash assistance (BLT), and capital assistance through the gate of the village (the village building movement). However, such poor communities in tourist areas Mamminasata hasn't been able to wrap of escape from poverty optimally

The cultural poverty that occurs in the area of Mamminasata, are the result of cultural factors of the community in the area is not in line with government policy. Jam its society, in general, have a low work ethic, lazy and love to expect government assistance as well as the party's relatives. (Amir, 21 June 2014, Regency Gowa).

Based on the description of the background of poverty that exists in the area of Mamminasata, it can be classified information obtained from the results of the Focus Group was held with the Discussion posited some fundamental issues faced by the community so that they are difficult to meet the necessities of life are worthy. The issue in question is as follows: 


\begin{tabular}{|c|c|}
\hline & $\begin{array}{l}\text { - Community-owned production equipment is very } \\
\text { limited, in particular for farmers is still limited } \\
\text { regarding the processing of rice field, rice milling. } \\
\text { - For their Fishing equipment limited with a potluck } \\
\text { so can't find fish on areal further as a result of the } \\
\text { catch is very little. } \\
\text { - For trade industry equipment production is very } \\
\text { limited so that no can work productively. For } \\
\text { example, the packaging becomes a major obstacle } \\
\text { for products; processing machinery is still limited. }\end{array}$ \\
\hline $\begin{array}{l}\text { The Development Potential of } \\
\text { The Local Economy }\end{array}$ & $\begin{array}{l}\text { - The development of local economic activity which } \\
\text { can drive productivity low income/poor society } \\
\text { - Limitations in production because of limited } \\
\text { ability in business financing. } \\
\text { - The low transformation technology into community } \\
\text { activities "so it becomes a constraint in economic } \\
\text { activity }\end{array}$ \\
\hline $\begin{array}{l}\text { Utilization of SDA \& } \\
\text { environment on an ongoing basis }\end{array}$ & $\begin{array}{l}\text {-The utilization of SDA optimally because of limited } \\
\text { knowledge and skills } \\
\text {-Penyuluha and mentoring society is still limited. } \\
\text {-Land tenure for people is very limited to have an } \\
\text { impact on their productivity }\end{array}$ \\
\hline
\end{tabular}

Source: Information Networking Results Through FGD

\section{It Examines The Strategies Of Empowerment That Comply With Local Communities}

Poverty became a study of importance in understanding the condition of an area at once society can understand the inequality of income in each region. Poverty is one of the issues that must be considered in the development, as one measure of the success of the construction was reducing poverty. So it has now happened a shift of meaning construction of orientation that prioritizes growth rate towards equitable development results. According to the traditional view, development has always identified with the per-capita income increase efforts made by the economic growth strategy (trickle down effect strategy) ".

Poor empowerment program should change the orientation of the pattern of the empowerment of the poor are oriented to the needs of the poor and not on the activities of the Government programs that are ceremonial and Santa Claus. Many Government empowerment programs especially in the area of Mamminasata, is a program oriented output, and not on learning outcomes, benefit, and impact. What we can get with a poverty reduction program that implemented in the area of Mamminasata, the answer is there haven't been a significant result.
Therefore the Government should change the pattern and orientation of policy in the empowerment of local communities.

In line with the area in this paper, a word that comes from informants "Thebecker.com. Amir Muharram" that the strategy and policy of the Government in empowering the community of a uniform strategy is derived by the Central Government to run throughout the area, so have a weakness in the achievement of the objectives, as each region has different characteristics from the environment and community, so that sometimes a program of empowerment do not accomplish a goal, but as a program will rate achievement capaiannya so implemented without considering local wisdom. (Gowa: 9. may 2017). "

The empowerment strategy for poverty reduction that is Santa Claus as a direct cash assistance programs (BLT) Although grounded with good cause, but the fact is not capable of encouraging the poor to become independent citizens. Therefore, the strategy of poverty reduction needs to be more emphasis on the social aspect of institutional empowerment and institutional economics.

$\begin{array}{lrr}\text { Institutional Social empowerment } \\ \text { includes among others; } & \begin{array}{r}\text { Institutional } \\ \text { entrepreneurship education, and }\end{array} \\ \text { institutional }\end{array}$


practices directly, farmers, institutional village, and Neighborhood, groups. Jemaah Taklim, group data pensions, to give the inner experience and the mental attitude change by developing a work ethic, togetherness in dealing with the problem of social community, foster togetherness and mutual nature as a manifestation of social capital of the community, to foster self-reliance.

While the Institutional Economic Empowerment by reinforcing market access, access to capital through institutional joint venture group (KUBE) and cooperatives. In this way, is expected to bring up the awareness of poor productive activities supported by institutional capital, and marketing, so that an increase in income and can reduce poverty.

The role of civic institutions such as the institution of the Village Council (LMD), community empowerment (LPM), the institution of village community Resilience (LKMD), construction of family welfare (PKK), the construction of the village Cadres (KPD), Companion of the village, and others need enhanced so that the public can more actively participate in the construction. Through the institutional activity carried out in the community can empower program through various institutional.

\section{Community Capacity Development as A Strategy}

What the low capability communities in accessing productive activity resulted in a society is not able to meet the needs of a decent life, as experienced by the community in the area of Mamminasa. The low capacity of community in empowering himself caused by the level of education owned society at large is still very low so that the impact on their ability to access productive activity. Therefore, it is important to make improvements to capacities community through a variety of activities that are fundamental.

Speaking communities in the area of the Mamminasa FGD activities presented in that most of our community groups below have low education, i.e. highest just finished high school, and most can only have completed. Middle school, our difficulty in doing so access to activities that are formal, we finally work on informal activities, such as vegetable sellers, sellers of fish, quality homebased cake making is not yet adequate. (15 July 2017 FGD in Gowa).

Capacity development community (community empowerment) can attempt with a variety of strategies adapted to various conditions and the potential that exists in the local community such as:

1. Improved quality and quantity of formal and non-formal education.

2. Quality improvement and extension of frequency

3. Mentoring Activities

4. Dissemination of information

Institutional Empowerment Society

Institutional village community that had made the means of empowering farmers is cooperatives/VILLAGE and farmers group (Poktan). However, the efforts of empowerment against the two institutions never completely done. Therefore, be reasonable if the empowerment of farmers is also half-hearted. Whereas, in statistic farmers or villagers is the largest community group.

\section{A Model of Institutional Empowerment Society}

The helplessness of society caused by the failure of institutional Poverty and unequal exchanges, not just in the process of exchange of commodities and unfair payment services over poor people or poor households by structure exploitative and perpetuate the dependence of poor households. It is necessary for the existence of a Government policy that favors the poor households.

Policies need to developed the creation of opportunities and economic opportunities for poor households. The strategy is the creation of opportunities, and economic opportunities should be able to include three things: (1) financing or capital assistance; (2) opening access to capital as well as the marketing of products; and (3) mentoring and improved business management skills.

A model of empowerment of the poor, performed with a change in their way of looking 
towards the self and its environment, the way the utilization of social capital, and the local community should be the main actors in each stage of development. A model of empowerment of the poor in the area of institutional strengthening is through Mamminasata locallybased local. To create the institutional strengthening of the community one is using a Participatory approach. The participatory approach is believed to be pushing the active role of the community so that it can form a strong social capital. Social capital is characterized by a strong institutional functioning of the community well. Empowering the poor through institutional development, based on the understanding of a whole range of nature and against the social capital they have, so that institutional design would be more appropriate.

Empowerment according to Parsons (1994) includes three dimensions (1) a development process that is on everything from individual growth, develop into a social change; (2) a psychological state characterized by confidence, a sense of useful and able to control yourself and others; (3) the exemption resulting from a social movement of people is weak and then involve the collective the efforts of the weak people to gain power and change the structures that are still pressing.

The results of the disclosure FGD participants Makassar City shows that the community generally marginal economy still difficulties in obtaining loans because of the requirement that there is no ability to be filled in the Bank because of our limitations as a weak economic community, could not run a business as desired by the Bank, but we also want things like that, but we have no power. We generally as informal businesses generally have only a desire to make an effort but need guidance and mentoring to understand how about trying to be successful. (Makassar, July 3, 2017).

For the poor, microfinance institutions' presence will help them get a loan capital to smooth their efforts and will strengthen the bargaining position and poor self-esteem. In some cases, the anti-poverty program conducted on the poor, unable to accommodate what is assessed both by the community, to bring up social resistance against what it says is good according to the program.

In some cases, poverty reduction program conducted by the Central Government, not in line with the policy of the local government. The Government, district of Maros Regency Takalar, Gowa, Makassar city and for example, a credit program for the people (KUR) have yet to be guaranteed by the Government are good, where Banks can only serve people in business who have the guarantee business and collateral. Then generally Community not able or the poor are still in very limited conditions with the requirements set out by the Bank but the Government cannot take a rare.

\section{Community Empowerment Strategies}

\section{a. Changes in the Paradigm of Development}

Development is a process of change leading to an increase in standard of living and welfare of the community. How far the construction of the process has been able to produce changes that impact on improving the standard of living and welfare of the community, as measured by the indicator indicators are generally economical. The size of the economy is quite varied, ranging from an emphasis on "growth" to take into account the "Equalization."

\section{b. Approaches in community empowerment} Development strategy which based on partiality and empowerment understood as a process of transformation in the relations of social, economic, cultural, and political communities. The expected structural changes are the process that takes place naturally, that that result should enjoy. Vice versa, who enjoy the must produce. The main approach to the concept of empowerment is that society is not made into objects of various development projects, but is the subject of its development efforts. Based on the concept of empowerment strategy, then the public should follow the approach as follows: first, that effort has to be focused. These are popularly called partiality. This effort aimed directly to that need, with programs designed to address the problem and fit his needs.

Second, the direct involvement of people approaches in the program of empowerment. This program must directly involve or even implemented by the target communities.

Third, use a group approach, because in its own poor hard can solve the problems it faces. Also 
the scope of assistance to be too wide if the handling is done individually. Group's most effective approaches and views of resource use are also more efficient.

Implementation of development programs which implement the community empowerment strategies constitutes consequences from a national development paradigm shifts that lead to the achievement of business development efforts centered on human beings (people-centered development).

Five important activities can do in community empowerment efforts:

1. Motivation. Members of the public can understand the value of community, social interaction and power through knowledge of their rights as citizens and members of the public.

2. Awareness raising and training ability. Increased public awareness can achieve through basic education, immunization, and sanitation of prisons. While the Polytechnic skills can develop through the ways participation.

3. Self-management. The Group should be able to choose their leader and organize their activities, such as carrying out meetings, do the recordkeeping and reporting, operating savings and credit, conflict resolution and management ownership Community.

4. Mobilization of resources. A method to gather the resources individually through regular savings and voluntary contributions with the aim of creating social capital.

5. The construction and development of the network. Organizing groups of NGOs need to be accompanied by an increase in the ability of its members to build and maintain a network with different social systems.

\section{The strategy of community development and Institutional.}

Based on the results of research that generally the poor who exist in the area of Mamminasata are those who work in the agricultural sector with a narrow land, urban communities that don't have access to productive activities, they can only work in the informal sector, with all its limitations so that they become unproductive

\section{External achieved}

Achieved in the external research is an implementation of the Model of Institutional Strengthening and Economic Social in Empowering the poor. The router is intended to be a reference for Governments, NGOs and private parties in empowering poor communities that can benefit the whole stakeholders related to the activities of the Empowerment community.

The benefits of Institutional Empowerment Model are to make instructions for the objects and subjects of the involved in the activity of empowerment, include; (a) poor as objects, (b) the individual as the subject of the empowerment of the poor, (c) the perpetrator of the empowerment as a motivator, (d) principals of empowerment as a Trainer, (e) perpetrators of empowerment as Cochi, and (f) the perpetrator of the empowerment as policymakers. Thus, the model can be helpful for the whole comment to understand the empowerment process, the procedure of execution of empowerment to close to the result of a model that in implementations in a program. 
Implementation of the Model of poverty alleviation Through social and economic Institutional empowerment of poor communities At Maminasata Area of South Sulawesi.

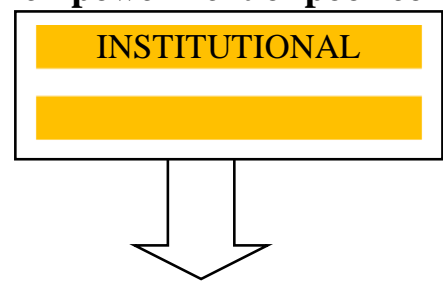

Institutional Social:The resilience of the Community institutionsLebaga community empowermentNongovernmental organizations-Educational InstitutionsHealth InstitutionsTraining Institutions

Institutional Economics:

-Cooperative

-Marketing

-Capital

-Group joint venture

-Farmer's Groups
The implementation of the institutional social and economic Model

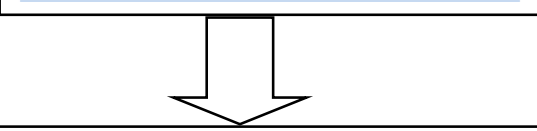

-Open access for the motivation and involvement of direct Community empowerment activities

-Increased Capacity Of Escort

-Do the mentoring community as a tiered-cadre recruitment Officer extension officers

-Empowerment of Officers Escort masy Empowerment.

-Empower Institutional maximum -Government and private Pemihakan in encouraging Institutional Strengthening -Government and private Support in strengthening institutional

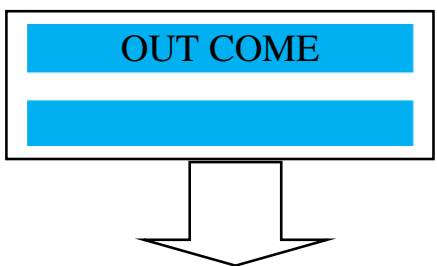

-The community become involved in activities and be able to do how to resolve problems encountered-The community has access on a social life and economic activity-The community is able to Help himself in solving problems faced by yg-Be creative and innovative Society-Position Masyarakan be powerful bargaining power within the community-The community prospered

Source: constructed from the research results

\section{Conclusion}

Based on the results of the discussion in this research it can be concluded in a few things as follows:

1. The poverty of the community in the area of Mamminasata caused by low the ability of the public access to education, health facilities, as well as limited support infrastructure in support of social and economic activities of the local community.

2. In general, the education and skills of the community still low to make the community faced limitations in live her life, especially in economic activity, so tend to be unproductive and inert, so it becomes poor.

3. Institutional social and Institutional Economics that exist within society in the area of Mamminasata, in General, cannot yet empower Community because it has not got the optimal support of the Government and private.

4. In general, the community within the Mamminasata does not yet have adequate skills in the conduct of social and economic activity, thus facing a lot of problem in her life from time to time cause of poverty tend to be experienced the increase from time to time, despite increasing economic growth. It indicates that there is inequality among communities in the region.

\section{BIBLIOGRAPHY}


[1] Basrowi dan Sudikin. 2002. Metode Penelitian Kualitatif Perspektif Mikro. Penerbit Insan Cendekia Surabaya.

[2] Bungin, Burhan. 2003. Metodologi Penelitian Kualitatif "Aktualisasi Metodologis Ke Arah Ragam Varian Kontemporer. PT. Raja Grafindo Persada Jakarta.

[3] Tim Crecent. 2003. Menuju Masyarakat Mandiri "Pengembangan Model Sistem Kesejahteraan Sosial", Penerbit PT Gramedia Pustaka Utama, Jakarta.

[4] Moleong, Lexy. J. 2006. Metodologi Penelitian Kualitatif. Edisi Revisi. Penerbit PT. Remaja Posdakarya Bandung.

[5] Muchtar. 2005. Strategi Pemberdayaan Berbasis Kelembagaan Lokal Dalam Penanggulangan Kemiskinan Perkotaan. Sumber: Google Tahun 2005

[6] .Nasir. 1985. Metode Penelitian. Penerbit Ghalia Indonesia, Jakarta Timur.

[7] Muhajdir, Noeng. 2000. Metodologi Penelitian Kualitatif, Edisi IV Cetakan Pertama, Penerbit Rake Sarasin Yoyakarta

[8] Nujum, Syamsu. 2001. Upaya Penanggulangan Kemiskinan Pada Desa Tertinggal Meluai Inpres Desa Tertinggal (IDT) di Sulawesi Selatan. Kerjasana LP2S UMI, dengan Dikti. (Dibiayai oleh DIKTI).

[9] Ridwan, M. 2008. Disertasi Doktor " Program Pemberdayaan Ekonomi dan Pengaruhnya Terhadap Kesejahteraan Masyarakat Pesisir. Universitas Brawijaya Malang.

[10] Riyadi dkk. 2003. Perencanaan Pembangunan Daerah; “ Strategi Menggali Potensi dalam Mewujudkan Otonomi Daerah". Penerbit PT Gramedia Puataka Utama, Jakarta.

[11] Salusu J.2002. Pengambilan Keputusan Stratejik : Untuk Organisasi Publik dan Orgnisasi Nonpropit. Penerbit PT. Gramedia Widiasarana Indonesia, Jakarta.

[12] Soeharto, Edi. 2005. Membangun Masyarakat Memberdayakan Rakyat. "KajianStrategi Pembangunan Kesehteraan Sosial dan Pekerja Sosial. Penernit Aditama Bandung.

[13] Sumodinigrat,. 2002. Membangun Ketahanan Ekonomi Indonesia Melalui Pemberdayaan Ekonomi Rakyat. Penerbit Universitas Sarjanawiyata Tamansisw, Yogyakarta.
[14] Yustika, A. 2006. Ekonomi Kelembagaan Defenisi, Teori dan Strategi. Penerbit Bayu Media Malang. 